\title{
Rational use of antibiotics and its guidelines in surgical patients-a retropspective study
}

\author{
Sengupta $S^{1}$, Pal B ${ }^{2}$, Bala $T^{3}$ \\ ${ }^{1}$ Dr Siladri Sengupta, Associate Professor in Surgery \& Unit Head, ${ }^{2}$ Dr Baneyswar Pal, Assistant Professor, ${ }^{3}$ Dr Tanuka \\ Bala, Junior Resident, Department of Surgery, ESI-PGIMSR \& Medical College Joka, Kolkata, West Bengal, India
}

Address for Correspondence: Dr Siladri Sengupta, Associate Professor in Surgery \& Unit Head, ESI-PGIMSR \& Medical College Joka, Kolkata, West Bengal, India

\begin{abstract}
Introduction: Rational use of drugs means to prescribe the appropriate drugs in correct dose over an adequate period of time at a lower cost. Irrational use of antibiotic is harmful both for the patient and the society and hence the top cause of mortality and morbidity around the world. So the aim of the present study is to - 1. Avoid adverse effect of irrational use of antibiotics on patient. 2. Avoid emergence of antibiotic resistance. 3. Avoid unnecessary increase of cost of health care. Methods: The study was conducted at the Surgery Unit II of the ESI-PGIMSR and ESIC Medical College, Joka, Kolkata- 700104, West Bengal. The Data was collected on random basis and the SSI was observed between the control and test group after rational and non rational treatment with antibiotics in some selected surgical patient. Results: It was found that in some diseases like acute gall bladder stone, cholecystitis, appendicitis, pancreatitis if some other antibiotics are additionally used besides the recommended as usual antibiotics the significant betterment is achieved in relation to quick recovery of the patients along with minimization of surgical site infection with no other complications. On the other hand in some other diseases like Diabetes foot, hernia, etc. use of antibiotics beyond the recommended antibiotics aggravates some other complications in the patients along with no significant betterment of surgical site infection in Test group. Conclusion: To conclude finally antibiotic resistance is a major problem worldwide and is inevitable and hence its rational use in proper guidelines is the only way of prolonging the useful life of the patients requiring antibiotics.
\end{abstract}

Keywords: Use of antibiotics, Rational, Irrational

\section{Introduction}

Antimicrobial resistance poses a great threat to human health and undermines national economics worldwide $[1,2]$. It is reported that this resistance is mostly due to consumption of antibiotics [3-5]. It is reported that in European countries, systemic antibiotics are prescribed in the greatest volumes to ambulatory patients, mostly for respiratory tract infections [6]. In Thailand, a study in a tertiary care hospital revealed that only $7.9 \%$ of the upper respiratory tract infections (URIs) in the facility were caused by bacteria [7]. Despite this, most URIs are treated with antibiotics by hospitals, health centers, drug stores and patients themselves [8-12]. Liberal use of antibiotics endangers the health of patients without observable clinical benefits, since it neither reduces the rate of complications nor quickens recovery when the illness is caused by a virus $[11,13]$.

Resistance against certain antibiotics is already at high

Manuscript Received: $04^{\text {th }}$ October 2016

Reviewed: $12^{\text {th }}$ October 2016

Author Corrected: $20^{\text {th }}$ October 2016

Accepted for Publication: $31^{\text {st }}$ October 2016 levels in certain places in India (and around the world) [14], but the problem has remained largely unknown because relatively few studies were published and nationwide surveillance was not being carried out. The fact that antibiotic use is increasing is not, itself, indicative of a problem, but evidence from studies of prescribing patterns suggests that antibiotics are often used in inappropriate ways that mostly results the microbial resistance. But unfortunately the antibiotic resistance surveillance has been limited to small-scale efforts by the Indian Council of Medical Research (ICMR) and

some private agencies on a pilot basis. This study is an attempt to study the judicial use of antibiotics which is rather known as Antibiotics smart use.

Rational use of drugs means to prescribe the appropriate drugs in correct dose over an adequate period of time at a lower cost [15]. Irrational use of antibiotic is harmful both 
for the patient and the society and hence the top cause of mortality and morbidity around the world [16,17]. When considering the role of antibiotics in the peri-operative period it is important to recognize the difference between prophylactic and empirical antibiotic therapy. The goal of prophylaxis is to reduce the post-operative infection assuming where the contamination might have occur but hasn't occurred [18], whereas in empirical therapy is based on operative findings as leakage of a viscous.

According to World Health report a study was conducted in 1993-1996 amongst 13 low, middle, and higher income countries and it shows that in $30 \%$ cases of UTI were incorrectly prescribed antibiotics [7,19]. Anti-microbial resistance is a global problem as a result infection fails to respond to standard treatment thereby decreasing the effect of effective antibiotic prolonging illness and risk of death. Under this situation it is always better to avoid the unnecessary complications in the patients due to unwanted and irrational use of antibiotics. So the aim of the present study is to -

1. Avoid adverse effect of irrational use of antibiotics on patient.

2. Avoid emergence of antibiotic resistance.

3. Avoid unnecessary increase of cost of health care.

\section{Materials}

Place of study: The study was conducted at the Surgery Unit II of the ESI-PGIMSR and ESIC Medical College, Joka, Kolkata - 700104, West Bengal.

Sample collection: The materials employed in this study are randomly selected from the surgical indoor patients admitted between Aug'15 to September ' 16 with various acute infection numbering 103 in total out of which male were 48 and female were 55 .

Inclusion criteria: The surgical patients attending OPD or admitted with acute or chronic surgical problems in indoor surgical wards requiring surgical management are included in this study.

Exclusion criteria: The patients attending OPD with primary medical problems which require immediate medical management and with coincidental chronic surgical problem which doesn't require surgical management for the time being are kept outside the study.

Study design: To observe the effect of rationally treated antibiotics the patients of pancretitits etc were divided into two group. One group (37) were treated with single recommended antibiotics considered as control whereas in second group (37) were treated with more than recommended antibiotics for recommended periods are labeled as Test group. After the recommended period of treatment the infection of surgical site (SSI) and other side effects were observed and compared. The details of number of patients are mentioned in the table at result section.

Similarly to observe the effect of non-rationally treated antibiotics the patients of hernia and etc were also divided into two group. One group were treated with single recommended antibiotics considered as control whereas in second group were treated with more than recommended antibiotics for recommended periods are labeled as Test group. After the recommended period of treatment the infection of surgical site (SSI) and other side effects were observed and compared. The details of number of patients are mentioned in the table at result section.

Statistical analysis: The statistical analysis of number of patients having SSI was compared between control group and test group by student's t test and significance level $<0.05$ was considered as statistically significant.

\section{Result}

It was found that in some diseases like acute gall bladder stone, cholecystitis, appendicitis, pancreatitis if some other antibiotics are additionally used besides the recommended as usual antibiotics the significant betterment is achieved in relation to quick recovery of the patients along with minimization of surgical site infection with no other complications. Table -I shows that use of additional antibiotics in test group along with recommended antibiotics significantly reduce the SSI in test group without any side effects or complications in comparison to control group which were treated only with recommended antibiotics. For example if the patients of acute gall stone after surgical removal of stone are treated with amikacin and metrogyl along with ceftriaxone /ciprofloxacilin the SSI was reduced to nil (Test group) in comparison to the patients who are treated only with ceftriaxone/ciprofloxacilin (Control group). On the other hand in some other diseases like Diabetes foot, hernia, etc. use of antibiotics beyond the recommended antibiotics aggravates some other complications in the patients as shown in the Table II along with no significant betterment of surgical site infection in Test group. For example if the patients with diabetic foot after surgical intervention was treated with clarithromycin along with augmentin (Test group) no reduction of surgical site infection was observed rather there is GI upset in such patients which was absent in patients treated only with augmentin (Control group ). 
Table I: Effect of rationally prescribed antibiotics on different diseases

\begin{tabular}{|c|l|l|l|l|}
\hline Disease & \multicolumn{2}{|l|}{ Control Group [37] } & Test Group [37] \\
\hline & $\begin{array}{l}\text { Recommended Antibiotic } \\
\text { Prescribed (No of patients) }\end{array}$ & $\begin{array}{l}\text { SSI observed } \\
\text { (No of } \\
\text { patients) }\end{array}$ & $\begin{array}{l}\text { Additional antibiotic } \\
\text { in treatment regime } \\
\text { (No of patients) }\end{array}$ & $\begin{array}{l}\text { SSI Observed } \\
\text { (No of } \\
\text { patients) }\end{array}$ \\
\hline Acute Gall stone & $\begin{array}{l}\text { Ceftriaxone / Ciprofloxacillin } \\
{[4]}\end{array}$ & 3 & $\begin{array}{l}\text { Amikacin \& Metrogyl } \\
{[4]}\end{array}$ & Nil \\
\hline Cholecystitis & $\begin{array}{l}\text { Ceftriaxone / Ciprofloxacillin } \\
{[16]}\end{array}$ & 11 & $\begin{array}{l}\text { Amikacin \& Metrogyl } \\
{[15]}\end{array}$ & 2 \\
\hline Acute Abdomen & $\begin{array}{l}\text { Ceftriaxone / Ciprofloxacillin } \\
{[4]}\end{array}$ & 4 & $\begin{array}{l}\text { Amikacin \& Metrogyl } \\
{[4]}\end{array}$ & Nil \\
\hline Pancreatitis & $\begin{array}{l}\text { Meropenum } \\
{[3]}\end{array}$ & 3 & $\begin{array}{l}\text { Metrogyl } \\
{[4]}\end{array}$ & 1 \\
\hline Appendicitis & $\begin{array}{l}\text { Ceftriaxone/ Cefotaxime } \\
{[6]}\end{array}$ & 4 & $\begin{array}{l}\text { Amikacin \& Metrogyl } \\
{[6]}\end{array}$ & 1 \\
\hline Colonic Growth & $\begin{array}{l}\text { Ceftriaxone / Cefotaxime } \\
{[4]}\end{array}$ & 4 & $\begin{array}{l}\text { Amikacin \& Metrogyl } \\
{[4]}\end{array}$ & Nil \\
\hline
\end{tabular}

. No within the parenthesis indicates the sample size

( Table -I shows that use of additional antibiotics in test group along with recommended antibiotics significantly reduce the SSI in test group in comparison to control group which were treated only with recommended antibiotics.)

Table - II: Effect of non-rationally prescribed antibiotics on different diseases

\begin{tabular}{|c|c|c|c|c|c|}
\hline \multirow[t]{2}{*}{ Disease } & \multicolumn{2}{|l|}{ Control Group (14) } & \multicolumn{3}{|l|}{ Test Group (15) } \\
\hline & $\begin{array}{l}\text { Recommended } \\
\text { Antibiotic } \\
\text { Prescribed (No of } \\
\text { patients) }\end{array}$ & $\begin{array}{l}\text { SSI } \\
\text { observed } \\
\text { (No of } \\
\text { patients) }\end{array}$ & $\begin{array}{l}\text { Additional } \\
\text { antibiotic } \\
\text { in treatment } \\
\text { regime (No of } \\
\text { patients) }\end{array}$ & $\begin{array}{l}\text { SSI } \\
\text { Observed } \\
\text { (No of } \\
\text { patients) }\end{array}$ & $\begin{array}{l}\text { Additional } \\
\text { complications } \\
\text { (No of patients) }\end{array}$ \\
\hline $\begin{array}{l}\text { Diabetic Foot } \\
\text { [7] }\end{array}$ & $\begin{array}{l}\text { Augmentin } \\
{[3]}\end{array}$ & 1 & Clarithromycin [4] & 1 & $\begin{array}{l}\text { G I upset } \\
\text { [3] }\end{array}$ \\
\hline $\begin{array}{l}\text { Breast Abscess } \\
{[10]}\end{array}$ & $\begin{array}{l}\text { Amoxycillin } \\
{[5]}\end{array}$ & 1 & Clarithromycin [5] & 4 & $\begin{array}{l}\text { Drug resistant } \\
\text { [4] }\end{array}$ \\
\hline $\begin{array}{l}\text { Hernia \& } \\
\text { Hydrocoele } \\
{[12]}\end{array}$ & $\begin{array}{l}\text { Ceftriaxone/ } \\
\text { Cefotaxime } \\
{[6]}\end{array}$ & 2 & $\begin{array}{l}\text { Amoxycilline \& } \\
\text { Clavulonic acid [6] }\end{array}$ & 2 & $\begin{array}{l}\text { GI upset } \\
{[6]}\end{array}$ \\
\hline
\end{tabular}

.No within the parenthesis indicates the sample size

( Table -II shows that use of additional antibiotics in test group along with recommended antibiotics failed to reduce the SSI in test group in comparison to control group which were treated only with recommended antibiotics. Rather use of additional antibiotics in test group aggravates some other complications like GI upset and etc.).

\section{Discussion}

The bacterial disease burden in India is among the highest in the world [2]; consequently, antibiotics will play a critical role in limiting morbidity and mortality in the country. Antibiotic use has been increasing steadily in recent years. Between 2005 and 2009, the units of antibiotics sold increased by about 40 per cent. Increased sales of cephalosporins were particularly striking, with sales (in units sold) increasing by 60 per cent over that five-year period, but some increase was seen in most antibiotic classes. The fact that antibiotic use is increasing is not, itself, indicative of a problem, but evidence from studies of prescribing patterns suggests that antibiotics are often used in inappropriate ways that mostly results the microbial resistance.

Antibiotics Smart Use (ASU) was introduced in 2007 as an innovative model to promote the rational use of medicines and counteract antimicrobial resistance. It was 


\section{Original Research Article}

established for two major reasons. First, the rational use of medicines as a concept was not always getting translated into practice, and the ASU model was felt to be useful in bridging this gap. Increasing awareness of antimicrobial resistance and promoting the rational use of antibiotics among prescribers and the general public are key to combating the unnecessary use of these drugs [6,16-18].

The present study revealed that judicial use of antibiotics can not only minimize the microbial resistance but also aggravates some other complications. This also demonstrate that non judicial use of antibiotics by using more than single recommended drug has no significant positive effect towards minimization of surgical site infection. This study is thereby is in accordance with many other studies investigated by other researchers worldwide [15-18].

Recommendation: On the basis of the result it is recommended that to achieve rational use of antibiotics for management of infection caused by microorganisms the following measures are to be employed.

1. Reducing the need for antibiotics by employing -

a- Antiseptic cleaning and draping of surgical site.

b-Use of dedicated surgical attire, disposable sterile gloves.

c- Sterilization of instruments

d-Isolation of surgical wound from other areas by draping.

2. Culture sensitivity of organisms to select the appropriate antibiotic and hence the chances of resistance are minimized.

3. Following the antibiotic guidelines like:
A - Is antibiotic necessary?
B - Most appropriate Antibiotic
$\mathrm{C}-$ What dose, route, frequency, duration?
D- Is the treatment effective ?

\section{Conclusion}

To conclude finally counseling should be performed at ward level. Awareness programs should be launched and seminars should be conducted. News Letters and drug bulletins about the rational use of antibiotics and its effect on community, cost effective prescriptions should be encouraged. All these facts are possible when clinical pharmacist work along with the physician at ward level.

Conflict of interest: None declared.

Funding: Nil, Permission from IRB: Yes

\section{References}

1. World Health Statistics. France: 2011. World Health Organization.

2. Kotwani A, Holloway K, Chaudhury RR. Methodology for surveillance of antimicrobials use among out-patients in Delhi. Indian J Med Res. 2009 May;129(5):555-60.

3. Mathew JL. Pneumococcal vaccination in developing countries: where does science end and commerce begin? Vaccine. 2009;27:4247-51.

4. Austin DJ, Kristinsson KG, Anderson RM. The relationship between the volume of antimicrobial consumption in human communities and the frequency of resistance. Proc Natl Acad Sci U S A. 1999 Feb 2;96(3):1152-6.

5. Laxminarayan R, Malani A, Howard D, Smith D. Washington, DC: 2007. [updated 2007; cited]. Policy responses to the growing threat of antibiotic resistance.

6. Goossens H. Antibiotic consumption and link to resistance. Clin Microbiol Infect. 2009 Apr;15 Suppl 3:12-5. doi: 10.1111/j.1469-0691.2009.02725.x.

7. Apisarnthanarak A, Mundy LM. Correlation of antibiotic use and antimicrobial resistance in Pratumthani, Thailand, 2000 to 2006. Am J Infect Control. 2008 Nov;36(9):681-2. doi: 10.1016/j.ajic.2007.10.022.

8. Albrich WC, Monnet DL, Harbarth S. Antibiotic selection pressure and resistance in Streptococcus pneumoniae and Streptococcus pyogenes. Emerg Infect Dis. 2004 Mar;10(3):514-7.

9. Chokejindachai W. Current situation of antimicrobial resistance in Thailand: a review. Nonthaburi: Health System Research Institute; 2007.

10. Jitraknatee A. Antibiotic values. In: Niyada KiatyingAngsulee, Nusaraporn Kessomboon, Usawadee Maleewong, editors. Situation report on drug system 2010: antimicrobial resistance. Bangkok: Drug System Monitoring and Development Center; 2011.

11. Bhavnani D, Phatinawin L, Chantra S, Olsen SJ, Simmerman JM. The influence of rapid influenza diagnostic testing on antibiotic prescribing patterns in rural Thailand. Int J Infect Dis. 2007 Jul;11(4):355-9. Epub 2007 Feb 26.

12. Suttajit S, Wagner AK, Tantipidoke R, Ross-Degnan D, Sitthi-amorn C. Patterns, appropriateness, and 
Original Research Article

predictors of antimicrobial prescribing for adults with upper respiratory infections in urban slum communities of Bangkok. Southeast Asian J Trop Med Public Health 2005; 36: 489-97.

13. Udomthavornsuk B, Tatsanavivat P, Patjanasoontorn B, Khomthong R, Bhuripanyo K, Saengnipanthkul S, Lumbiganon P, Wiengnond S, Boonma P, Vongsangnak $\mathrm{V}$, et al. Intervention of inappropriate antibiotic use at a university teaching hospital. J Med Assoc Thai. 1991 Oct;74(10):429-36.

14. Pagaiya N, Garner P. Primary care nurses using guidelines in Thailand: a randomized controlled trial. Trop Med Int Health 2005; 10: 471-7 doi: 10.1111/j.1365-3156.2005.01404.x.

15. Earnshaw S, Monnet DL, Duncan B, O'Toole J, Ekdahl K, Goossens H; European Antibiotic Awareness
Day Technical Advisory Committee; European Antibiotic Awareness Day Collaborative Group. European Antibiotic Awareness Day, 2008 - the first Europe-wide public information campaign on prudent antibiotic use: methods and survey of activities in participating countries. Euro Surveill. 2009 Jul 30;14(30):19280.

16. Selecteddrug used indicator World Health Organization 1 Academic Press (1998). The World Medicins Situation20.

17. Swindell PJ, Reeves DS, Bullock DW, Davies AJ, Spence CE. Audits of antibiotic prescribing in a Bristol hospital. Br Med J (Clin Res Ed). 1983 Jan 8;286(6359):118-22.

18. Gonzales R, Steiner JF, Sande MA. Antibiotic prescribing for adults with colds, upper respiratory tract infections, and bronchitis by ambulatory care physicians. JAMA. 1997 Sep 17;278(11):901-4.

\section{How to cite this article?}

Sengupta S, Pal B, Bala T. Rational use of antibiotics and its guidelines in surgical patients-a retropspective study.Int $J$ surg Orthopedics. 2017; 3(2):33-37.doi:10.17511/ijoso.2017.i02.02. 